\title{
RATES AND METHODS OF APPLYING UREA TO COMMON BEANS ${ }^{1}$
}

\author{
J.C. KIEHL; R.I. SILVEIRA
}

Departamento de Ciencia do Solo - ESALQUSP, Caixa Postal, 9 - CEP: 13418-900 - Piracicaba,SP - Brazil

J. BRITO NETO

Empresa de Pesquisa Agropecuaria de Alagoas, CEP: 58.600-000 - Maceib, AL - Brazil.

\begin{abstract}
The effect of rate and method of urea application on the yield of common beans (Phaseolus vulgaris L., cv. IPA-1) was evaluated on a Red-Yellow Latosol (Psamentic Haplortox) of Arapiraca and on a Solodic Planosol (Ustalf) of Igaci, both sandy-clay-loams located in the State of Alagoas, Brazil. Rates of 30,60 and $90 \mathrm{~kg}$ N/ha were applied placing the urea totally in the furrow at planting time; totally sidedressed twenty days after planting, mixed or not with the soil; or 1/3 of the amount in the furrow at planting plus 2/3 sidedressed twenty days after planting, mixed or not with the soil. Bean yield responses to nitrogen followed quadratic equations. In the Red-Yellow Latosol response to nitrogen occurred up to the rate of $66 \mathrm{~kg}$ N/ha, while in the Solodic Planosol the yield increased up to the highest applied rate of $90 \mathrm{~kg} N / \mathrm{ha}$. The relative yield increase for each site was $22 \%$ and $16 \%$; respectively. Sidedressed application of the total amount of urea resulted in the lowest yields, whereas split application and furrow fertilization were the best and equally effective methods. No significant yield increase was observed by mixing the urea with the soil.
\end{abstract}

Key Woris: bean, urea, nitrogen, method of application.

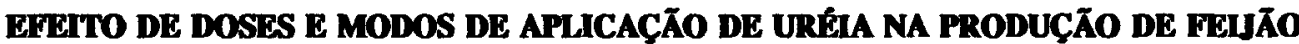

RESUMO: 0 efeito de doses e modos de aplicação de uréia na produção de feijāo (Phaseolus vulgaris L., cv. IPA-1) foi avaliado em um latossolo vermelho-amarelo de Arapiraca (AL) e em um planossolo solódico de Igaci (AL), ambos franco-argilo-arenosos. Doses de 30,60 e $90 \mathrm{~kg} / \mathrm{ha}$ de $\mathrm{N}$ foram aplicadas totalmente no sulco de plantio, totalmente em cobertura aos vinte dias após o plantio com ou sem incorporação, e 1/3 no sulco de plantio mais 2/3 em cobertura com ou sem incorporaçāo. A produção de fejjão aumentou com a dose de nitrogênio segundo equaçōes quadrátricas. No latossolo vermelho-amarelo, o feijão respondeu à aplicação de nitrogenio até a dose de $66 \mathrm{~kg} / \mathrm{ha}$ de $\mathrm{N}$, enquanto no planossolo solódico a produçăo aumentou até a dose maior de $90 \mathrm{~kg} / \mathrm{ha}$ de $\mathrm{N}$. Os aumentos respectivos de produçăo em cada local foram de $22 \%$ e $16 \%$. A aplicaçāo de uréia de uma só vez em cobertura conferiu as menores produçōes, enquanto o fracionamento da dose em duas aplicaçð̃es, bem como a adição única no plantio, foram os melhores métodos e igualmente efetivos. Não houve aumento significativo da produção de fejjão com a incorporação da urcia no solo.

Descritores: feijão, uréia, nitrogênio, método de aplicação.

\section{INTRODUCTION}

Use of urea as a nitrogen source for crops has substantially increased in Brazil during the last fifteen years. Nevertheless, reliable information on the amount and methods of urea application to the various crops cultivated under the extremely different climates of Brazil are rare or even absent.

The very low average productivity of common beans in Brazil, though the result of various factors, can be linked directly to the use of insufficient amounts of fertilizers (ROSOLEM, 1987). In spite of being a leguminous plant, bean crops need a certain amount of combined nitrogen in the soil during the initial stages of growth to stimulate nodule formation in the roots and increase nitrogen fixation (RUSCHEL \& SAITO, 1977). Considering that the proportion of experiments with positive responses of beans to nitrogen application in our country is around 30\% (IGUE, 1968 and MALAVOLTA, 1972), it is possible that the demand of additional amounts of nitrogen in the soil by this crop is not high. In fact, according to IGUE (1968), in most cases yield increases of bean have been observed only up to 30 $\mathrm{kg} \mathrm{N} / \mathrm{ha}$. Occasionally, responses may be obtained for rates up to $150 \mathrm{~kg} \mathrm{~N} / \mathrm{ha}$ (PONS, 1979; FEITOSA et al., 1980; and DELAZARI, 1981).

\footnotetext{
' Research supported by Projeto Uréia, contract PETROFÉRTIL/NITROFÉRTIL-NE/ULTRAFÉRTLLSA/LCS-ESALQ.
} 
Several experiments were carried out in different regions of Brazil to study the effect of rates, methods and time of urea application on the yield of cotton (KIEHL et al., 1985) and corn (MELLO et al., 1988). This work presents the results of two similar experiments undertaken with beans in different soils in the inland of the State of Alagoas.

\section{MATERIALS AND METHODS}

Two field experiments were conducted on the following soils and localities: Red-Yellow Latosol (Psamentic Haplortox) of Arapiraca and Solodic Planosol (Ustalf) of Igaci, both sandy clay loam located in the State of Alagoas, Brazil. The chemical properties of these soils are shown in TABLE 1.

Factorial treatments were arranged in a randomized complete block design with four replications. Rates of urea equivalent to 30,60 and $90 \mathrm{~kg} \mathrm{~N} / \mathrm{ha}$ were applied by placing the urea totally in the furrow at planting; totally sidedressed, mixed or not with the soil twenty days after planting; or $1 / 3$ in the furrow at planting plus $2 / 3$ sidedressed, mixed or not with the soil twenty days after planting. Mixing was made with a shovel, to the depth of about $4 \mathrm{~cm}$. A no-nitrogen control treatment was included. All plots received application of $80 \mathrm{~kg} \mathrm{P}_{2} \mathrm{O}_{5} / \mathrm{ha}$ in the form of simple superphosphate and $20 \mathrm{~kg} \mathrm{~K} \mathrm{~K}_{2} \mathrm{O} / \mathrm{ha}$ as potassium chloride, at planting.

Plots consisted of six rows $10 \mathrm{~m}$ long and spaced $0.60 \mathrm{~m}$. Common bean (Phaseolus vulgaris L., cv. IPA-1) seeds were planted at the rate of fifty seeds per meter, following the application of the fertilizers in a lateral furrow. After emergence the number of seedlings was reduced to five per meter. Yield of grain was measured for eight meters of each of the four central rows of each plot, one hundred days after planting. Data were evaluated by analysis of variance ( $F$ value); the effect of rates of urea was determined by regression analysis, whereas the effect of methods of application was studied by means of the Duncan's test.

\section{RESULTS AND DISCUSSION}

\section{Rates of urea application}

The interaction "rate of urea $x$ method of application" was not significant in the experiment conducted on the Red-Yellow Latosol, but bean yield in this site increased with the applied rate of urea according to a quadratic equation (Figure 1). Response to nitrogen application occurred up to the rate of $66 \mathrm{~kg} \mathrm{~N} / \mathrm{ha}$, which corresponded to a maximum yield of $2.53 \mathrm{t} / \mathrm{ha}$ of beans, a yield increase of $463 \mathrm{~kg} / \mathrm{ha}(22 \%)$ over the control treatment.

In the Solodic Planosol the interaction "rate of urea and method of application" was also non-significant. A quadratic response was obtained as well, but in this case the yield increased progressively with the rate of urea application (Figure 1). Response to nitrogen reached $90 \mathrm{~kg}$ $\mathrm{N} / \mathrm{ha}$, with a yield of $2,923 \mathrm{~kg} / \mathrm{ha}$ of beans; compared to the control, the bean yield increased $411 \mathrm{~kg} / \mathrm{ha}(16 \%)$ in this soil.

Considering the results of similar experiments reported in the literature for the bean crop, the responses observed here for both experiments are satisfactory.

For example, from 88 experiments conducted in the states of Ceará, Pernambuco, Sergipe, Bahia, Goiás, Espírito Santo, São Paulo and Rio Grande do Sul, only 27 (30.7\%) showed positive response to nitrogen fertilization. Among the studies showing low number of responses are those reported by MIYASAKA et al. (1966e) and by CARVALHO et al. (1974), with only one response in eight and nine experiments, respectively, and those carried out by MIYASAKA et al. (1966a,c,f; 1967b) and by the DNOCS (BRASIL, 1973), with no response in a total of 21 experiments.

Data compiled from 54 field experiments on nitrogen fertilization of beans in the State of São Paulo (MALAVOLTA, 1972) show responses of the crop in $32 \%$ of the cases, while data collected by IGUE (1968) from 50 field experiments in the same state reveal a rate of only $28 \%$ of significant responses.

Other researchers have reported yield increases for nitrogen application up to the highest applied rate such as MIYASAKA et al. (1966b,d; $1967 \mathrm{a}, \mathrm{c})$ up to $60 \mathrm{~kg} \mathrm{~N} / \mathrm{ha}$, de PONS (1979) and FEITOSA et al. (1980) up to $90 \mathrm{~kg} \mathrm{~N} / \mathrm{ha}$ and DELAZARI (1981) up to $120 \mathrm{~kg} \mathrm{~N} / \mathrm{ha}$ in two experiments in the State of Espirito Santo. Experiments conducted in two different regions of the State of Parana in 1978 and 1980, reported by LANTMANN et al. (1985), showed reactions of the crop to the addition of $\mathrm{N}$ up to 120 and $40 \mathrm{~kg}$ $\mathrm{N} / \mathrm{ha}$ for each region. 
TABLE 1. Some chemical properties of the $0-20 \mathrm{~cm}$ layer of the soils at the experimental sites ${ }^{(1)}$

\begin{tabular}{ccccccccc}
\hline Soil & $\mathrm{pH}$ & $\mathrm{C}$ & $\mathrm{PO}_{4}$ & $\mathrm{~K}$ & $\mathrm{Ca}$ & $\mathrm{Mg}$ & $\mathrm{Al}$ & $\mathrm{H}+\mathrm{Al}$ \\
\hline & & $\%$ & \multicolumn{7}{c}{$\mathrm{me} / 100 \mathrm{~g}$} \\
Red-Yellow Latosol & 6.1 & 1.20 & 0.04 & 0.44 & 4.08 & 1.10 & 0.10 & 3.30 \\
Solodic Planosol & 6.1 & 0.66 & 0.14 & 0.36 & 1.62 & 0.62 & 0.14 & 2.89 \\
\hline \hline
\end{tabular}

(1) $\mathrm{pH}$ in 1:2.5 soil:water suspension; $\mathrm{C}$ by digestion with $\mathrm{K}_{2} \mathrm{Cr}_{2} \mathrm{O}_{7}$ and $\mathrm{H}_{2} \mathrm{SO}_{4} ; \mathrm{PO}_{4}$ extracted with $0.05 \mathrm{~N}$ $\mathrm{H}_{2} \mathrm{SO}_{4} ; \mathrm{Ca}, \mathrm{Mg}$ and $\mathrm{Al}$ extracted with $1 \mathrm{~N} \mathrm{KCl} ; \mathrm{H}+\mathrm{Al}$ extracted with $1 \mathrm{~N}$ calcium acetate at $\mathrm{pH}$ 7.0.

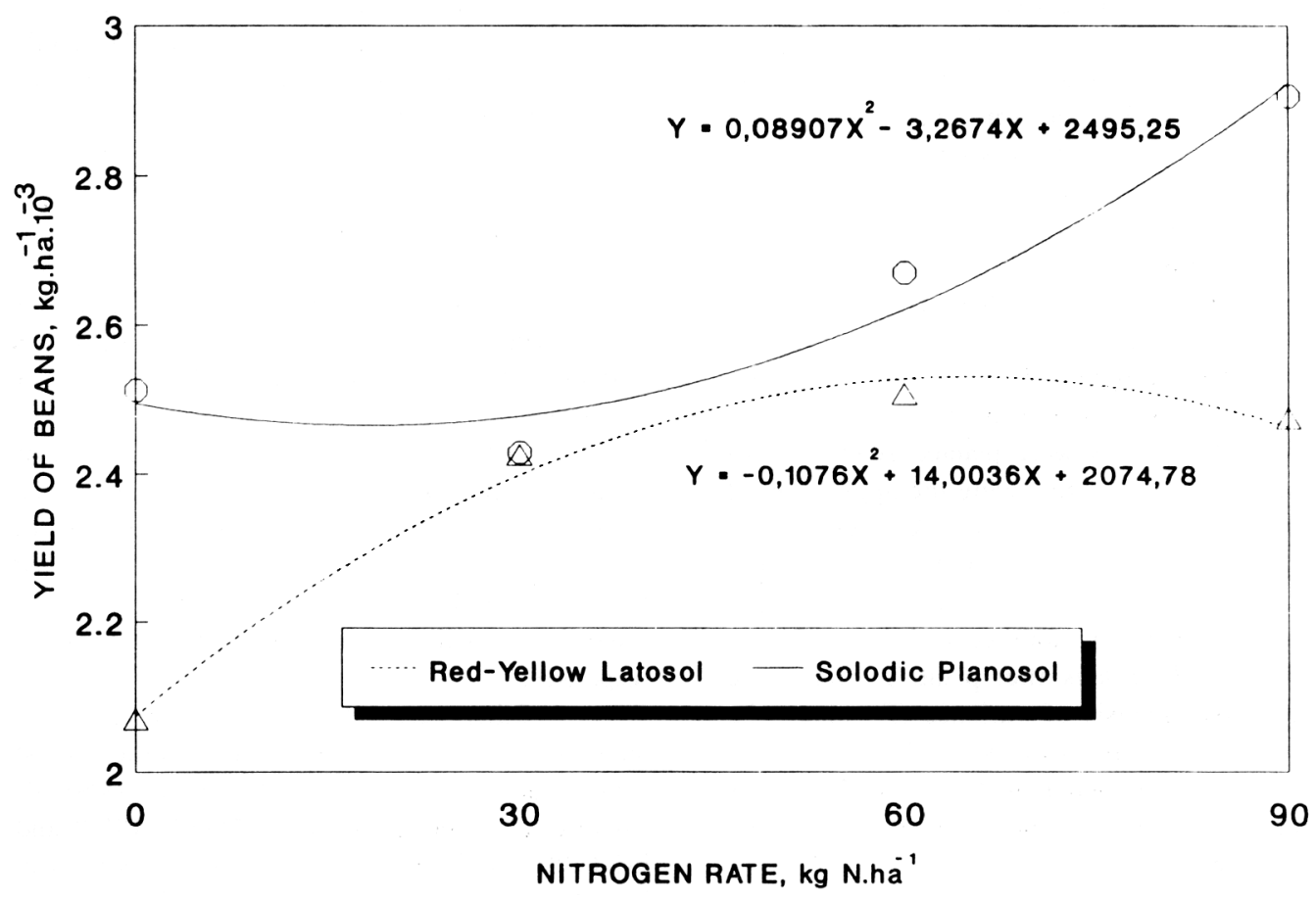

Figure 1 - Effect of nitrogen application on the yield of common beans in two soils of Alagoas, Brazil 
TABLE 2 - Effect of methods of application of urea on the yield of common beans in two soils of Alagoas, Brazil $^{(1)}$

\begin{tabular}{lcc}
\hline \hline & \multicolumn{2}{c}{ Yield of beans } \\
\cline { 2 - 3 } Method of application & \multicolumn{2}{c}{$\mathrm{kg} / \mathrm{ha}$} \\
\cline { 2 - 3 } & Red-Yellow Latosol & Solodic Planosol \\
\hline Totally in the furrow at planting & $2399 \mathrm{ab}$ & $2747 \mathrm{a}$ \\
Totally sidedressed, not mixed with the soil & $2282 \mathrm{ab}$ & $2537 \mathrm{ab}$ \\
Totally sidedressed, mixed with the soil & $2233 \mathrm{~b}$ & $2431 \mathrm{~b}$ \\
$1 / 3$ in the furrow plus $2 / 3$ sidedressed, not mixed with the & $2447 \mathrm{a}$ & $2673 \mathrm{ab}$ \\
soil & & \\
$1 / 3$ in the furrow plus $2 / 3$ sidedressed, mixed with the soil & $2447 \mathrm{a}$ & $2673 \mathrm{ab}$ \\
\hline \hline
\end{tabular}

(1) Within each column, Figures followed by one or two letters in common are not significantly different according to Duncan's test at $P<0.05$.

\section{Methods of urea application}

The effect of methods of application of urea on the yield of beans was significant in both experiments. In the Red-Yellow Latosol the application of urea totally sidedressed gave the lowest yields, even when the fertilizer was mixed with the soil to avoid ammonia loss by volatilization (TABLE 2). Split application (1/3 of the nitrogen in the furrow at planting plus $2 / 3$ sidedressed twenty days after planting) and application of the total amount at planting were the most efficient methods, with yield increases of up to $402 \mathrm{~kg} / \mathrm{ha}$ of beans. Considering that these methods were not significantly different from each other, it becomes apparent that splitting the nitrogen was not an advantageous practice.

The results observed for the crop in the Red-Yellow Latosol, as regarding the methods of applying urea, were confirmed in the Solodic Planosol, as the yields obtained when the fertilizer was totally applied at planting or split in two applications were higher than those achieved with a single sidedressed application (TABLE 2); the yield increase was, in this case, up to $245 \mathrm{~kg} / \mathrm{ha}$ of beans. Probably the split application was not more effective than other methods because of the limited rainfall $(750 \mathrm{~mm} /$ year $)$ at both experimental sites.
Results in the literature are divergent with respect to the best method of applying urea to the bean crop. MIYASAKA et al. (1963) found that nitrogen application at emergence of seedling was superior to applications after 22,42 or 62 days, while MASCARENHAS et al. (1966) did not observe, in two experiments, any difference in bean yield when nitrogen was applied after 7,14 , and 21 days from emergence. The same was reported by KORNELIUS et al. (1976) when comparing nitrogen application at planting with applications after 15 and 30 days from emergence. SILVA et al. (1977) and URBEN FILHO et al. (1980) found no yield increase by splitting the amount of nitrogen applied to beans.

In opposition to these authors, LAROCHE et al. (1967) found, in some of the seven experiments carried out in the northeastern Brazil, that five applications of nitrogen spaced fifteen days resulted in higher yields than three applications each thirty days or a single application at planting. MEIRELLES et al. (1980), measuring the amount of nitrogen absorbed by a bean crop and the amount leached out of root zone, have suggested that the split application, $1 / 3$ at planting plus $2 / 3$ after 30 or 45 days, should be recommended for maximum utilization of the nutrient by the crop. 
Results presented in TABLE 2 clearly show that mixing urea with the soil in sidedressed applications was not a better method than applying the fertilizer on soil surface. This observation was hold even considering that large amounts of ammonia can be lost by volatilization if urea is applied on soil surface, and that this loss can be severely reduced by placing the fertilizer a few centimeters below the surface or by mixing it with a certain amount of soil (OVERREIN \& MOE, 1967; ANJOS \& TEDESCO, 1974 and 1976; CAMPOS \& TEDESCO, 1979; RODRIGUES \& KIEHL, 1986). Although ammonia losses have been widely detected by direct measurements in laboratory and field experiments, the beneficial effect of burying urea into the soil on crop growth and yield has not been demonstrated. This can be seen in field experiments conducted with corn (PONS \& NUSS, 1980 and 1981; COUTINHO et al., 1984; and MELLO et al., 1988), with sorghum (COUTINHO, 1983) and with cotton (KIEHL et al., 1985). It is possible that the transport of urea into the soil by rain water may play an important role in reducing ammonia loss. It is also possible that in some cases the amount of nitrogen lost in gaseous form is not sufficiently high to influence the yield.

\section{CONCLUSIONS}

- Bean yield responses to nitrogen followed quadratic equations. In the Red-Yellow Latosol response to nitrogen occurred up to the rate of 66 $\mathrm{kg} \mathrm{N} / \mathrm{ha}$, while in the Solodic Planosol the yield increased up to the highest applied rate of $90 \mathrm{~kg}$ $\mathrm{N} / \mathrm{ha}$. The relative yield increase for each site with respect to non fertilized control was $22 \%$ and $16 \%$, respectively.

- Sidedressed application of the total amount of urea after $\mathbf{2 0}$ days from emergence resulted in the lowest bean yields, whereas split application and furrow fertilization were the best and equally effective methods; therefore, no advantage was observed by splitting nitrogen application. No significant yield increase was observed by mixing the urea with the soil.

\section{REFERENCES}

ANJOS, J.T. \& TEDESCO, M.J. Perdas de nitrogênio, por volatilização de amónia, proveniente de uréia aplicada em solos cultivados. In: CONGRESSO BRASILEIRO DE CIÊNCIA DO SOLO, 14., Santa Maria, 1973. Anais. Santa Maria, Sociedade Brasileira de Ciência do Solo, 1974. p.232-241.

ANJOS, J.T. \& TEDESCO, M.J. Volatilização de amônia proveniente de dois fertilizantes nitrogenados aplicados em solos cultivados. Científica, Jaboticabal, v.4, p.49-55, 1976.

BRASIL. Departamento Nacional de Obras Contra a Seca. DNOCS. Cultura do feijão; adubação subtrativa. Seminário de avaliação de resultados de experimentação agrícola em perímetros do DNOCS. $\mathrm{s} / 1, \mathrm{~s} / \mathrm{e}, 1973$. p.12-17.

CAMPOS, A.X. \& TEDESCO, M.J. Eficiência da uréia e do sulfato de amônio na cultura do milho Zea mais L.). Agronomia Sulriograndense, Porto Alegre, v.15, p.119-125, 1979.

CARVALHO, B.C.L.; MENDES, J.E.S.; GOMES.J.C.: SANTOS, D.P.; NUNES, J.A.C.; FRANCO, C.B.; LEITE, J.M. Adubação mineral do feijoeiro Phaseolus vulgaris L. no Estado da Bahia- Efeitos de $N, P, K, S$ e de uma mistura de micronutrientes (B, $\mathrm{Zn}, \mathrm{Cu}$ e Mo) nas regiōes de Irecê e Tucano. In: Secretaria da Agricultura, Bahia. Projeto Feijāo. Salvador, Secretaria da Agricultura, 1974. p.119-140.

COUTINHO, E.L.M. Efeitos da adubação uitrogenada, fosfatada e potássica na cultura do sorgo sacarino (Sorghum bicolor L. Moench), avaliada pela diagnose foliar, produção de colmos e alcool etalico. Piracicaba, 1983. 89p. Tese (Doutorado) - Escola Superior de Agricultura "Luiz de Queiroz", Universidade de São Paulo.

COUTINHO, E.L.M.; FORMIGONI Jr., A.; SOUZA, E.C.A.; CARNIER, P.E. Aplicação de uréia na cultura do milho. Efeitos de doses, modos de aplicação e parcelamento. In: REUNIÃO BRASILEIRA DE FERTILIDADE DO SOLO, 16., Illéus, 1984. p.58.

DELAZARI, P.C. Rendimentos económicos de três cultivares de feijāo (Phaseolus vulgaris $\mathrm{L}$.) em função da aplicaçāo de nitrogênio e fósforo. Revista Brasileira de Ciência do Solo, Campinas, v.5, p.4650, 1981.

FEITOSA, C.T.; RONZELLI- Ir., P.; D'A de ALMEIDA, L.; VEIGA, A.A.; HIROCE, R.; JORGE, J.P.N. Adubação NP para o fejjoeiro (Phaseolus vulgaris L.) na presença e na ausência de calcário. Revista Brasileira de Ciência do Solo, Campinas, v.4, p.156-159, 1980. 
IGUE, T. Interações em grupos de experimentos de adubação do feijoeiro com $\mathrm{N}, \mathrm{P}$ e $\mathrm{K}$, seguindo o esquema fatorial $3 \times 3 \times 3$. Piracicaba, 1968. 81p. Dissertação (Mestrado) - Escola Superior de Agricultura "Luiz de Queiroz", Universidade de São Paulo.

KIEHL, J.C.; BRASIL SOBRINHO, M.O.C.; SILVA, M.C. Efeito de doses e modos de aplicação de uréia na produção de algodāo. Revista Brasileira de Ciência do Solo, Campinas, v.9, p.39-44, 1985.

KORNELIUS, E.; SOBRAL, L.F.; GOMES, J.S.; RODRIGUES, E.M. Efeitos de doses e épocas de aplicação de nitrogênio na produção de feijão. In: CONGRESSO BRASILEIRO DE CIÊNCIA DO SOLO, 15., Campinas, 1975. Anais. Campinas, Sociedade Brasileira de Ciência do Solo, 1976. p.225-228.

LANTMANN, A.F.; OLIVERA, E.L.; CHAVES, J.C.D.; PAVAN, M.A. Adubação nitrogenada no Brasil. Ithéus, Sociedade Brasileira de Ciencia do Solo, 1985. p.19-46.

LAROCHE, F.A.; LUCAS, A.F.; OLIVERA, A.A.; BANDEIRA, E.V.; SANTOS FILHO, D.C. Experimento de fertilidade em solos de tabuleiros: resultados dos efeitos de calagem e adubação com a cultura do feijāo mulatinho, Phaseolus vulgaris. Recife, SUDENE, 1967. 16p. (Brasil, SUDENE, Agricultura, 7)

MALAVOLTA, E. (coord.) Nutrição e adubação. In: SIMPÓSIO BRASILEIRO DE FEIJĀO, 1., Viçosa, 1971. Anais. São Paulo, Ministério da Agricultura, 1972. p.209-242.

MASCARENHAS, H.A.A.; MIYASAKA, S.; IGUE, T.; VEIGA, A.A.; ALVES, S. Influência das formas de fertilizantes nitrogenados e suas épocas de aplicação na cultura do feijoeiro. Bragantia, Campinas, 25:XLI-XLIII, 1966.

MEIRELLES, N.M.F.; LIBARDI, P.L.; REICHARDT, K. Absorção e lixiviação de nitrogênio em cultura de feijāo (Phaseolus vulgaris L.). Revista Brasileira de Ciência do Solo, Campinas, v.4, p.83-88, 1980.

MELLO, F.A.F.; ARZOLLA, S.; KIEHL, J.C.; BRITO NETO, J. Efeito de doses e modos de aplicação de uréia na produção de milho. Revista Brasileira de Ciência do Solo, Campinas, v.12, p.269-274, 1988.

MIYASAKA, S.; FREIRE, E.S.; ALVES, S.; ROCHA, T.R. Adubação mineral do feijoeiro. III. Efeitos de $N, P, K$, da calagem e de uma mistura de enxôfre $e$ micronutrientes, em solo massapé-salmourão. Bragantia, Campinas, v.25, p.179-188, 1966a.

MIYASAKA, S.; FREIRE, E.S.; IGUE, T.; CAMPANA, M. Adubação mineral do feijoeiro. II. Efeitos de N, P, K, da calagem e de uma mistura de enxôfre e micronutrientes, em terra-roxa-misturada. Bragantia, Campinas, v.25, p.145-160, 1966 b.

MIYASAKA, S.; FREIRE, E.S.; IGUE, T.; SCHMIDT, N.C.; LETTE, N. Adubação mineral do feijoeiro. V. Efeitos de N, P, K, S e de uma mistura de micronutrientes, em dois solos do Vale do Paraíba. Bragantia, Campinas, v.25, p.307-316, $1966 \mathrm{c}$.

MIYASAKA, S.; FREIRE, E.S.; IGUE, T.; TEÓFILO SOBRINHO, J.; ALMEIDA, L.D. Resposta do feijoeiro à aplicaçāo de diversos tipos de matéria orgânica não decomposta, na presença de adubaçōes minerais com P, PK, NP ou NPK. Bragantia, Campinas, v.26. p.335-344, 1967a.

MIYASAKA, S.; FREIRE, E.S.; MASCARENHAS, H.A.A. Modo e época de aplicação de nitrogênio na cultura do feijoeiro. Bragantia, Campinas, v.22, p.511-519, 1963.

MIYASAKA, S.; FREIRE, E.S.; MASCARENHAS, H.A.A.; IGUE, T.; PARANHOS, S.B. Adubação mineral do feijoeiro. $X$. Efeitos de $N, P, K, S$ e de uma mistura de micronutrientes, em terra-roxalegítima e terra-roxa-misturada. Bragantia, Campinas, v.26, p.287-302, 1967 b.

MIYASAKA, S.; FREIRE, E.S.; MASCARENHAS, H.A.A.; PETTINELLI, A.; IGUE, T. Adubação mineral do feijoeiro. VIII. Efeitos de N, P, K, $S$ e de uma mistura de micronutrientes, em novas experiencias conduzidas em Tatuí e Tietê. Bragantia, Campinas, v.25, p.393-406, 1966d.

MIYASAKA, S.; MASCARENHAS, H.A.A.; FREIRE, E.S.; IGUE, T.; SORDI, G. Adubaçāo mineral do feijoeiro. DX. Efeitos de N, P, K, S e de uma mistura de micronutrientes, em "terra-roxa-misturada" previamente tratada, ou não, com calcário dolomítico e adubação verde com labelabe. Bragantia, Campinas, v.26, p.161-180, 1967c.

MIYASAKA, S.; MASCARENHAS, H.A.A.; FRERE, E.S.; ROCHA, T.R.; ALVES, S.; ISSA, E. Adubação mineral do feijoeiro. VI. Efeitos de N, P, $\mathrm{K}, \mathrm{S}$ e de uma mistura de micronutrientes em solo massapê-salmourão. Bragantia, Campinas, v.25, p.371-392, 1966e.

MIYASAKA, S.; PETTINELLI, A.; FREIRE, E.S.; IGUE, T. Adubação mineral do feijoeiro. IV. Efeitos 
de $N, P, K$, da calagem e de uma mistura de enxôfre e micronutrientes, em Tietê e Tatur. Bragantia, Campinas, v.25, p.297-316, $1966 \mathrm{f}$.

OVERREIN, L.N. \& MOE, P.G. Factors affecting urea hydrolysis and ammonia volatilization in soil. Proceedings of Soll Science Society of America, Madison, v.31, p.57-61, 1967.

PONS, A.L. Efeito da adubação nitrogenada, fosfatada e potíssica sobre o rendimento de feijāo em dois solos do Rio Grande do Sul. In: CONGRESSO BRASLEIRO DE CIÉNCIA DO SOLO, 17., Manaus, 1979. Resumos. Campinas, Sociedade Brasileira de Ciência do Solo, 1979. p.51.

PONS, A.L. \& NUSS, C.N. Efeito de metodo de aplicaçåo de nitrogénio na cultura do milho. In: REUNIĀO TÉCNICA ANUAL DO MILHO, 25. , Porto Alegre, 1980. Anais. Porto Alegre, IPAGRO, 1980. p.27-30.

PONS, A.L. \& NUSS, C.N. Efeito de metodos de aplicagão de nitrogénio em cobertura na cultura do milho. In: REUNIÃO TÉCNICA DO MILHO, 26., Porto Alegre, 1981. Anais. Porto Alegre, IPAGRO, 1981.

RODRIGUES, M.B. \& KIEHL, J.C. Volatilização de amônia após emprego de uréia em diferentes doses e modos de aplicação. Revista Brasileira de Ciência do Solo, Campinas, 10:37-43, 1986.
ROSOLEM, C.A. Nutrição e adubação do fejoeiro. Piracicaba, Associação Brasileira para Pesquisa da Potassa e do Fosfato, 1987. 93p. (Boletim Técnico, 8).

RUSCHEL, A.P. \& SATTO, S.M.T. Efeito da inoculação de Rhizobium, nitrogênio e matéria orgânica na fixação simbiótica de nitrogênio em feijão (Phaseolus vulgaris L.). Revista Brasileira de Ciencia do Solo, Campinas, v.1, p.11-24, 1977.

SILVA, M.I.; DARIVA, T.; KAMINSKI, J.; XAVIER, F.M. Efeito de níveis e épocas de aplicação de nitrogênio na produção do feijão (Phaseolus vulgaris L.). Revista do Centro de Ciencias Rurais, Santa Maria, v.7, p.395-401, 1977.

URBEN FILHO, G.; CARDOSO, A.A.; VIEIRA, C.; FONTES, L.A.N.; THIÉBAUT, J.T.L. Doses e modos de aplicação do adubo nitrogenado na cultura do feijâo (Phaseolus vulgaris L.). Revista Ceres, Viçosa, v.27, p.302-312, 1980.

Received March, 041993

Accepted April 04, 1993

Trabalho entregue para publicaçāo em 04.03 .93

Trabalho aprovado para publicação em 04.04 .93 